\title{
Influence of Government Accounting Standards and Internal Control System on the Achievement of Auditor Opinion
}

\author{
Suryanih ${ }^{1, *}$ Hari Setiyawati ${ }^{2}$ Ratna Mappanyuki ${ }^{3}$ \\ 1,2,3 Universitas Mercu Buana \\ *Corresponding author. Email: suryanihrafif@ gmail.com
}

\begin{abstract}
In order to obtain an unqualified opinion, several instruments that are used as a standard for achieving opinion are required, including the application of government accounting standards and sufficiently good internal controls so that the management of financial statements can be accounted for in accordance with applicable regulations. Data was collected by distributing questionnaires to the administration and finance of each regional work unit to get the correct data. government accounting standards do not have a good impact on the achievement of opinion if it is not implemented by the government both central and regional and internal control can have a good impact on the achievement of opinion.
\end{abstract}

Keywords: Auditor Opinion, Government Accounting Standards, Internal Control System

\section{INTRODUCTION}

Problems regarding the quality of local government financial reports are interesting to discuss. Some cases regarding the poor quality of local government financial reports are still very important to be studied more deeply. This happens because of the lack of competence and knowledge of government officials in implementing Government Accounting Standards (SAP) well for the presentation of financial statements.

The implementation of the Government Accounting Standards imposed in 2015 has not run optimally [1]. There were several obstacles faced by the regions in implementing the new Accounting Standards [1]. Constraints faced include the quantity of human resources (HR) managing finances, competencies, and commitment of regional heads in encouraging the optimization of the application of financial-based financial reports in area. Research on Government Accounting Standards has been carried out [2] on the effect of applying government accounting standards on the quality of financial reports, the results show that the application of government accounting standards has a positive and significant effect on the quality of local government financial reports. These results are in line with the research conducted by Nugraeni and Budiantara [3] which state that government accounting standards directly influence the quality of financial statements.
The effectiveness of the internal control system increasingly provides direction for the government in the implementation of the preparation of financial statements, a series of actions, procedures and even policies can be carried out by the Government in the framework of preparing financial reports in accordance with the applicable legislation. The internal control system implemented by the Regional Government greatly influences opinions on the Regional Government Financial Statements. This is also in line with the results of Kieso and Wardield [4] which stated that the internal control system had an effect on the financial report opinion.

The formulation of the problem in this study is whether the Application of Government Accounting Standards influences the achievement of auditor opinion if modified by the effectiveness of the internal control system. This study aims to examine the effect of applying Government Accounting Standards on the achievement of auditor opinion if moderated by the effectiveness of the internal control system.

\section{LITERATURE REVIEW}

\subsection{Government Accounting Standards}

Government accounting standards are accounting principles applied in compiling and presenting government financial reports. Each reporting entity of the 
central government and local government must implement SAP (Government Accounting Standards). PSAP consists of several parts, namely: 1) PSAP Number 1 concerning Presentation of Financial Statements; 2) PSAP Number 2 concerning Budget Realization Report; 3) PSAP Number 3 concerning Cash Flow Statements; 4) PSAP Number 4 concerning Notes to Financial Statements; 5) PSAP Number 5 concerning Inventory Accounting; 6) PSAP Number 6 concerning Investment Accounting; 7) PSAP Number 7 concerning Accounting for Fixed Assets; 8) PSAP Number 8 concerning Construction Accounting in Progress; 9) PSAP Number 9 concerning Accounting for Obligations; 10) PSAP Number 10 concerning Correction of Errors, Changes in Accounting Policies and Extraordinary Events; 11) PSAP Number 11 concerning Consolidated Financial Statements [5].

"Government accounting standards are the accounting principles established in compiling and presenting government financial reports" [6]. While the definition of Government Accounting Standards is "Government Accounting is an integral of the accounting discipline. It is the basic concepts underlying the accounting for whole and shares many characteristics with commercial accounting" [7].

\subsection{Internal Control System}

Internal control as follows, Internal control - analyze the standard by which companies design analyze and evaluate internal control [8]. In this section, the objectives of internal control are described, followed by a discussion of how these objectives can be achieved through the integrated framework's five elements of internal control. The definition of Internal Control is: A system of internal control and assurance that company achieves its objectives and goals [9]. They make up the entity's internal control. Internal control system is a process that is designed and implemented by the board of commissioners or management to provide adequate assurance that the control objectives have been achieved so that they can help achieve company goals. In addition to the aforementioned statements, Government Regulation number 60 of 2008 concerning the Government's Internal Control System, defines internal control as follows: Internal Control System is an integral process in actions and activities carried out continuously by the leadership and all employees to provide adequate assurance for achieving organizational goals through effective and efficient activities, reliability of financial reporting, safeguarding state assets, and compliance with laws and regulations ". The purpose of the internal control system there are three, namely: 1) Reliability of financial reporting; 2) Efficiency and effectiveness of operations; 3) Compliance with laws and regulations [9].

\subsection{Auditor Opinion}

Concerning Examination of Management and Responsibility of State Finance article 1 paragraph 11 opinion is a professional statement as the conclusion of the examiner regarding the level of fairness of information presented in financial statements [10]. The audit opinion is stated in an audit report consisting of three paragraphs, namely the opening paragraph, the paragraph of scope and the paragraph of opinion. The opening paragraph identifies audited financial statements and states that the financial statements are the responsibility of the entity's management. While the auditor or examiner is the person who carries out the task of examining the management and responsibility of state finances for and on behalf of the Audit Board [11]. The auditor or examiner has the duty to conduct an examination of the financial statements prepared by the organization or institution. Based on the Law of the Republic of Indonesia No. 15 of 2004 concerning the Examination of Management and Responsibility of State Finance, the types of opinions given by the BPK RI contained in the Standard Statement for Examination of 300 Republic of Indonesia Supreme Audit Agency Regulation Number 1 of 2017 concerning State Financial Examination Standards, auditor opinion divided into four, namely Unqualified Opinion, Qualified Opinion, Adverse Opinion and Statement Refusing to Give Opinion

\subsection{Thinking Framework}

From research on the Effect of Government Accounting Standards on the Quality of Financial Reports and Their Implications for Performance Accountability, government accounting standards directly influence the quality of financial statements. SAP application to the quality of financial statements [3]. In line with previous research conducted by Badan Pemeriksa Keuangan Republik Indonesia [12] with the title The Effect of Understanding of Government Accounting Standards and Internal Control Systems on Quality of Finacial Statement from Local Government through a Review of the Process of Financial Statement by the Inspectorate Agency stated that there was a significant influence from understanding of Government Accounting Standards on the Quality of Financial Statements.

The system is a combination of various elements in an organization both private and government that are incorporated in one container so that the flow of information, energy, material, vision and mission and work plans can be carried out in accordance with what has been determined for general and specific purposes both private and government organizations. according to the Government Regulation of the Republic of Indonesia number 60 of 2008 concerning the Internal Control System the Government states that "The Internal Control 
System is an integral process in actions and activities carried out continuously by the leadership and all employees to provide adequate confidence in achieving organizational goals through effective activities and efficient, reliability of financial reporting, safeguarding state assets, and compliance with laws and regulations ", so that a good internal control system is expected to have a positive impact on opinions obtained by both private and government organizations after an external auditor audits. As research conducted by [13] which states that the weak internal control system can affect the opinions that will be given by the Supreme Audit Agency (BPK).

The research framework model of this study can be seen in the picture as follows:

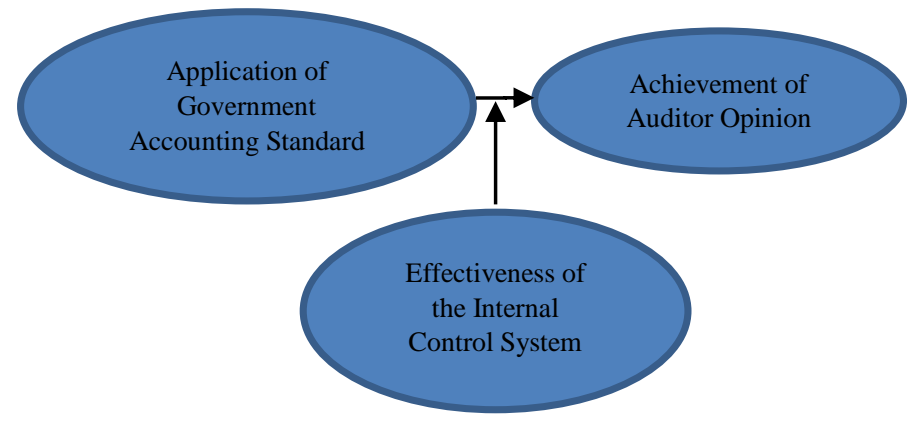

Figure 1. Thinking Framework

\subsection{Hypothesis}

Based on the framework that was stated earlier, the research hypothesis can be arranged as follows:

H1: Application of government accounting standards has a significant effect on the auditor opinion.

$\mathrm{H} 2$ : The effectiveness of the internal control system has a significant effect on the auditor opinion.

H3: The effectiveness of the internal control system moderates the significant effect of the implementation of government accounting standards on the achievement of opinion.

\section{METHODS}

This research is explorative (exploratory study) with a type of causal study where the researcher wants to find the cause of one or more problems [14]. In this study, the effect of the Implementation of Government Accounting Standards on the Achievement of Auditor Opinion is moderated by the Effectiveness of the Internal Control System. The target population as a whole unit of analysis in this study is the entire Regional Government Work Unit of the City of Tangerang. Because Tangerang is a local government which is a model for other regions. The sample is determined by using saturated samples, ie all populations are sampled. Data were analyzed using Smart PLS software. The stages of testing are carried out as follows: Analysis of Descriptive Statistics, Test of
Validity and Reliability, Evaluation of Goodness of Fit, and Hypothesis Test.

\section{RESULTS AND FINDINGS}

\subsection{Descriptive statistics}

The average value of the variable in the Application of Government Accounting Standards is 4,320 with a very high category. The lowest score of 4,628 is found in the basic accrual dimension and the highest score of 4,047 is found in the dimensions of realization as shown in the following table

Table 1. Description of Variables of the Application of Government Accounting Standards

\begin{tabular}{|c|l|c|c|}
\hline No & \multicolumn{1}{|c|}{ Dimensions } & Score & Category \\
\hline 1 & Accounting Based & 4,628 & Very High \\
\hline 2 & Historical Value & 4,302 & Very High \\
\hline 3 & Realization & 4,047 & High \\
\hline 4 & $\begin{array}{l}\text { Substance } \\
\text { Outperforms the } \\
\text { Formal Form }\end{array}$ & 4,221 & Very High \\
\hline 5 & Periodicity & 4,581 & Very High \\
\hline 6 & Consistency & 4,419 & Very High \\
\hline 7 & Full Disclosure & 4,326 & Very High \\
\hline 8 & $\begin{array}{l}\text { Reasonable } \\
\text { Presentation }\end{array}$ & 4,372 & Very High \\
\hline & Average & 4,320 & Very High \\
\hline
\end{tabular}

Source: Primary data processed, 2019

Table 2 below shows the average value of the variable dimensions of the Internal Control System's effectiveness of 4,284 in the very high category. The lowest score of 3,953 is in the risk assessment dimension and the highest score of 4,504 is in the dimensions of the Control Activity.

Table 2. Description of Variables of The Effectiveness of The Internal Control System

\begin{tabular}{|c|c|c|c|}
\hline No & Dimensions & Score & Category \\
\hline 1 & Control Environment & 4,395 & Very High \\
\hline 2 & Risk Assessment & 3,953 & High \\
\hline 3 & Control Activities & 4,504 & Very High \\
\hline & Average & 4,284 & Very High \\
\hline
\end{tabular}

Source: Primary data processed, 2019

The average value of the indicators of the Internal Control System Effectiveness variable is 4,284 with very high categories. The lowest score of 3,302 is in budget constraints and the highest score is 4,535 in the 
transaction approval and transaction verification indicators, as shown in the following table:

Table 3. Description of Variables of The Auditor Opinion Achievement

\begin{tabular}{|c|c|c|c|}
\hline No & Dimensions & Score & Category \\
\hline 1 & Unqualified Opinion & 4.372 & Very High \\
\hline 2 & Qualified Opinion & 4.171 & High \\
\hline & Nilai Rata-rata & 4.271 & Very High \\
\hline
\end{tabular}

Source: Primary data processed, 2019

Based on Table 3 above, it can be explained that the average value of the research dimension of the variable
Auditor Opinion is 4,271 with a very high category. The lowest score of 4,171 is found in the dimensions of fair opinion with exceptions and the highest score of 4,372 is found in the dimension of unqualified opinions. The following is a description of the research indicators of auditor opinion achievement variables.

\subsection{Test of Validity and Reliability}

The following is the result of the output loading factor constructing the application of government accounting standards that has a significant effect on the opinion outcomes moderated by the effectiveness of the internal control system on Smart PLS:

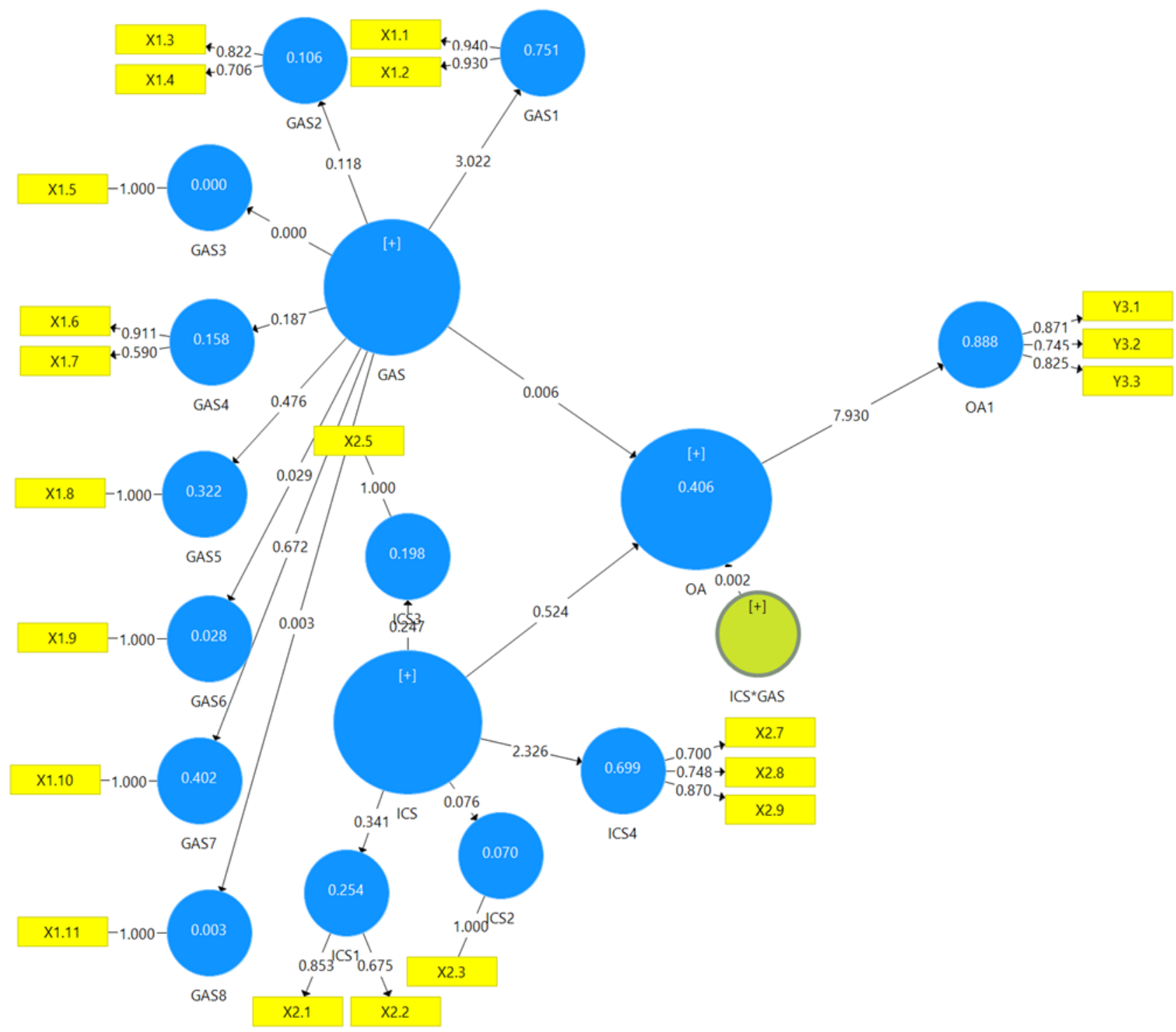

Figure 2. Output Loading

Based on the output on the path diagram above, the loading factor has met convergent validity, i.e. the indicator value is above 0.5. All loading factors are significant at the $5 \%$ level. In addition to the picture above, a validity test table that describes the factor loading for each indicator is shown as follows:

Table 4. Validity Test Results 


\begin{tabular}{|c|c|c|}
\hline No & Statement X1 (Application of GAS ) & $\begin{array}{l}\text { Loading } \\
\text { Factor }\end{array}$ \\
\hline 1 & $\begin{array}{l}\text { Local government financial } \\
\text { statements present a balance sheet } \\
\text { based on the basis set out in PP No. } \\
71 \text { About GS }\end{array}$ & 0.940 \\
\hline 2 & $\begin{array}{l}\text { The local government financial report } \\
\text { presents a Budget Realization Report } \\
\text { based on the basis stipulated in the } \\
\text { legislation concerning the budget, } \\
\text { namely the cash basis. }\end{array}$ & 0.930 \\
\hline 3 & $\begin{array}{l}\text { The valuation of fixed assets is based } \\
\text { on fair value at the time of } \\
\text { acquisition. }\end{array}$ & 0.822 \\
\hline 4 & $\begin{array}{l}\text { Assessment of obligations is carried } \\
\text { out if there is no historical value. }\end{array}$ & 0.706 \\
\hline 5 & Fair Presentation of Transactions. & 1.000 \\
\hline 6 & $\begin{array}{l}\text { Presentation of other accounting } \\
\text { events. }\end{array}$ & 0.911 \\
\hline 7 & $\begin{array}{l}\text { Reporting period in accordance with } \\
\text { applicable policies. }\end{array}$ & 0.590 \\
\hline 8 & $\begin{array}{l}\text { Application of accounting methods in } \\
\text { accordance with SAP. }\end{array}$ & 1.000 \\
\hline 9 & $\begin{array}{l}\text { Completeness of financial statement } \\
\text { information needed for decision } \\
\text { making. }\end{array}$ & 1.000 \\
\hline 10 & $\begin{array}{l}\text { Presentation of Budget Realization } \\
\text { Reports, Changes to More Budget } \\
\text { Balance Reports, Balance Sheets, } \\
\text { Operational Reports, Cash Flow } \\
\text { Reports, Changes in Equity Reports } \\
\text { and Notes to Financial Statements are } \\
\text { presented in a reasonable and } \\
\text { appropriate manner. }\end{array}$ & 1.000 \\
\hline 11 & $\begin{array}{l}\text { Transaction reconciliation is needed } \\
\text { to match the values between those } \\
\text { reported and those recorded }\end{array}$ & 1.000 \\
\hline
\end{tabular}

\begin{tabular}{|c|l|c|}
\hline No & Statement X2 ( Effectiveness ICS ) & $\begin{array}{c}\text { Loading } \\
\text { Factor }\end{array}$ \\
\hline 1 & $\begin{array}{l}\text { In carrying out their duties and } \\
\text { responsibilities, employees are } \\
\text { required to have high integrity }\end{array}$ & 0.853 \\
\hline
\end{tabular}

\begin{tabular}{|c|c|c|}
\hline 2 & $\begin{array}{l}\text { Upholding ethical values in carrying } \\
\text { out duties and functions is a must } \\
\text { for employees }\end{array}$ & 0.675 \\
\hline 3 & $\begin{array}{l}\text { Employees are placed in } \\
\text { accordance with the competence } \\
\text { of human resources and their } \\
\text { qualifications, skills and knowledge }\end{array}$ & 1.000 \\
\hline 4 & $\begin{array}{l}\text { In carrying out duties and } \\
\text { responsibilities in accordance with } \\
\text { the main tasks and functions, } \\
\text { always refer to the prevailing laws } \\
\text { and regulations }\end{array}$ & 1.000 \\
\hline 5 & $\begin{array}{l}\text { The technology and application } \\
\text { systems used in the preparation of } \\
\text { reports for each period must follow } \\
\text { the development of existing } \\
\text { technology }\end{array}$ & 0.700 \\
\hline 6 & $\begin{array}{l}\text { Every transaction or use of the } \\
\text { budget must go through } \\
\text { transaction approval from the } \\
\text { competent authority }\end{array}$ & 0.748 \\
\hline 7 & $\begin{array}{l}\text { Transactions that occur are verified, } \\
\text { both the transaction value and the } \\
\text { number of units }\end{array}$ & 0.870 \\
\hline No & $\begin{array}{l}\text { Statement Y (Achievement of } \\
\text { Auditor Opinion) }\end{array}$ & $\begin{array}{l}\text { Loading } \\
\text { Factor }\end{array}$ \\
\hline 1 & $\begin{array}{l}\text { The financial statements prepared } \\
\text { for each accounting period are } \\
\text { prepared in accordance with } \\
\text { applicable accounting standards }\end{array}$ & 0.871 \\
\hline 2 & $\begin{array}{l}\text { In the presentation of financial } \\
\text { statements there is no justification } \\
\text { for material errors that affect the } \\
\text { condition of the financial } \\
\text { statements }\end{array}$ & 0.745 \\
\hline 3 & $\begin{array}{l}\text { Transactions reflected in financial } \\
\text { statements are supported by } \\
\text { sufficient evidence }\end{array}$ & 0.825 \\
\hline
\end{tabular}

The following is a table of results of reliability testing on latent variables. The application of government accounting standards has a significant effect on opinion outcomes, moderated effectiveness of internal control systems: 
Table 5. Reliability Test Results

\begin{tabular}{|c|c|c|c|c|}
\hline $\begin{array}{c}\text { Variable \& } \\
\text { Dimension } \\
\mathrm{s}\end{array}$ & AVE & $\begin{array}{l}\text { Cronbac } \\
\text { h's Alpha }\end{array}$ & $\begin{array}{c}\text { Composi } \\
\text { te } \\
\text { Reliabilit } \\
\text { y }\end{array}$ & $\begin{array}{c}\text { Informati } \\
\text { on }\end{array}$ \\
\hline $\begin{array}{l}\text { Applicatio } \\
n \text { of the } \\
\text { GAS }(X 1)\end{array}$ & $\begin{array}{c}0.51 \\
6\end{array}$ & 0,811 & 0.865 & Reliable \\
\hline $\begin{array}{l}\text { Effectivene } \\
\text { ss of } \\
\text { Internal } \\
\text { Control } \\
\text { System } \\
(X 2) . . \\
\text { Moderatin } \\
\text { g }\end{array}$ & $\begin{array}{c}0.56 \\
1\end{array}$ & 0.719 & 0.790 & Reliable \\
\hline $\begin{array}{l}\text { Achieveme } \\
\text { nt of } \\
\text { Auditor } \\
\text { Opinion(Y) }\end{array}$ & $\begin{array}{c}0.54 \\
1\end{array}$ & 0.828 & 0.874 & Reliable \\
\hline ISCE*GAS & $\begin{array}{c}1.00 \\
0\end{array}$ & 1.000 & 1.000 & \\
\hline
\end{tabular}

Source: Primary data processed, 2019

The following is a table of results of reliability testing on latent variables. The application of government accounting standards has a significant effect on opinion outcomes, moderated effectiveness of internal control systems.

\subsection{Evaluate the Goodness of Fit Structural Model (Inner Model).}

Table 6 below explains the results of the coefficient of determination analysis of the research variables:

Table 6. R-Square

\begin{tabular}{|l|c|c|}
\hline \multicolumn{1}{|c|}{ Variable } & $\begin{array}{c}\text { R } \\
\text { Square }\end{array}$ & $\begin{array}{c}\text { R Square } \\
\text { Adj }\end{array}$ \\
\hline $\begin{array}{l}\text { Achievement of Auditor } \\
\text { Opinion }(Y)\end{array}$ & 0.406 & 0.360 \\
\hline \multicolumn{2}{|l|}{ Source: Primary data processed, 2019 }
\end{tabular}

Based on the determination coefficient in the table above, the R2 value for the auditor opinion achievement variable is 0.406 , which means that the value indicates that the auditor opinion achievement model is explained by the application of government accounting standards and the effectiveness of the internal control system by $40.6 \%$ while the rest is $59,4 \%$ is explained by other variables not found in the research model.

\subsection{Hypothesis Testing}

To test the hypothesis in this study, the T-statistic value of each pathway is partially direct influence. The following is a picture that explains the path diagram to test the hypothesis: 


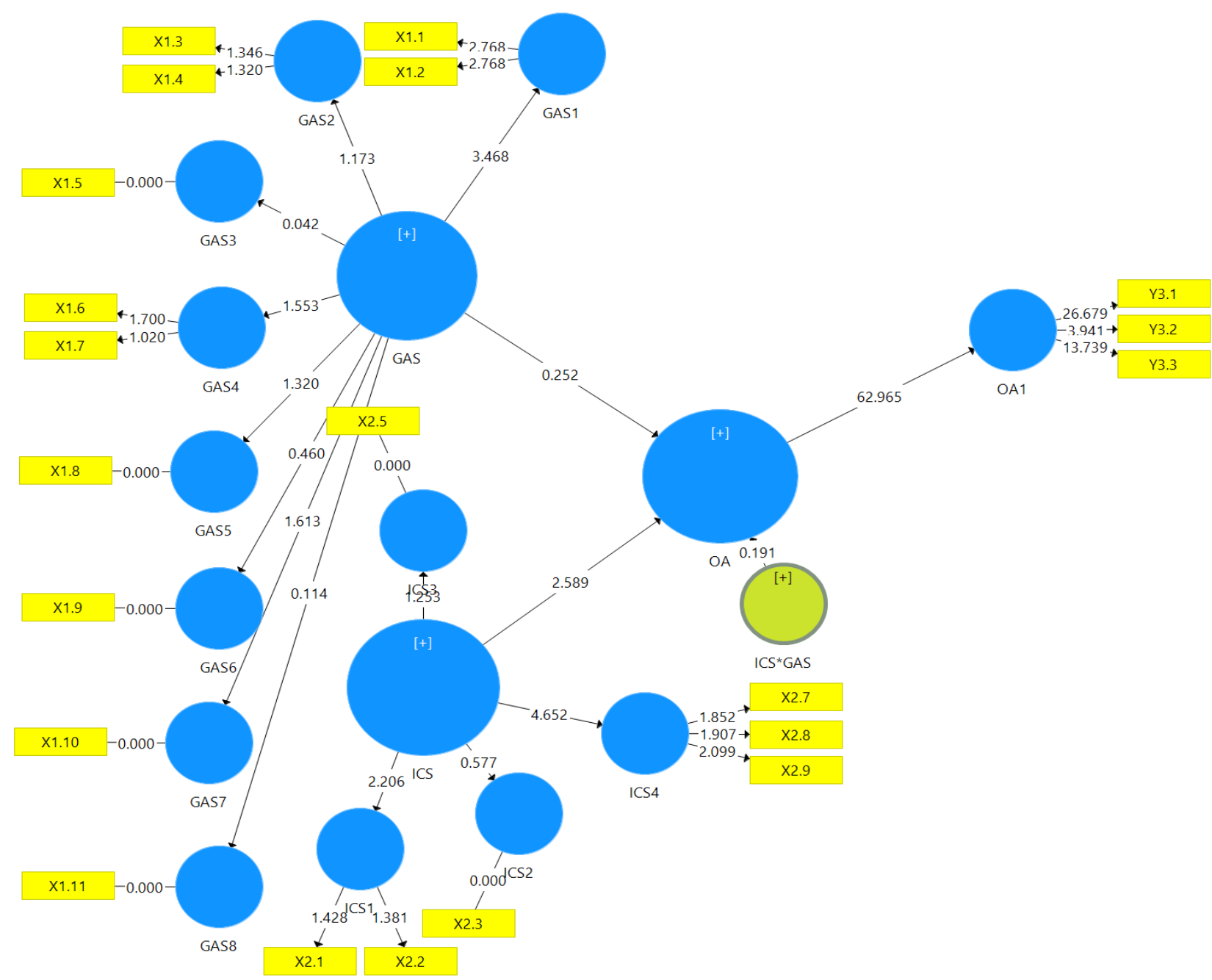

Figure 3. Output Inner Model

\begin{tabular}{|l|c|c|c|c|}
\hline \multicolumn{1}{|c|}{ Inter-Variable Relationships } & $\begin{array}{c}\text { Coefficient } \\
\text { Parameter }\end{array}$ & $\begin{array}{c}\text { T } \\
\text { Statistic }\end{array}$ & $\begin{array}{c}\text { Palues } \\
\text { Vaformatio } \\
n\end{array}$ \\
\hline Application of The GAS -> Achievement of Auditor Opinion & 0.068 & 0.252 & 0.400 & $\begin{array}{c}\text { No } \\
\text { Significant }\end{array}$ \\
\hline $\begin{array}{l}\text { Effectiveness of Internal Control System ->Achievement of } \\
\text { Auditor Opinion }\end{array}$ & 0.619 & 2.589 & 0.002 & Significant \\
\hline ICSE*GAS-> Achievement of Auditor Opinion & -0.041 & 0.191 & 0.425 & $\begin{array}{c}\text { No } \\
\text { Significant }\end{array}$ \\
\hline
\end{tabular}

Table 7. Path Coefficients

Inf.: Significant at level 5\%

The path parameter coefficient obtained from the influence of the application of government accounting standards on the achievement of auditor opinion is 0.068 with a T-statistic value of $0.252<1.660$ at a significance level of $\alpha=0.05(5 \%)$ and $P$ values of 0.400 above 0.05 which suggest that there is no effect government accounting standards for auditor opinion achievements. The results of this study do not support the first hypothesis, namely there is the influence of the application of government accounting standards to the achievement of auditor opinion.

The path parameter coefficient obtained from the effect of the effectiveness variable of the internal control system on the achievement of auditor opinion is 0.619 with a statistical value of $2.589>1.660$ at the significance level $\alpha=0.05(5 \%)$ and $\mathrm{P}$ values of 0.002 below 0.05 which suggest that there is an effect on system effectiveness internal control of the auditor's opinion. 
The results of this study support the second hypothesis, namely there is the effect of the effectiveness of the internal control system on the achievement of auditor opinion. The value of 0.619 in the parameter coefficient means that the more obedient applying government accounting standards, the easier it is to achieve unqualified auditor opinion.

The path parameter coefficients obtained from the influence of the variables of government accounting standards on the achievement of auditor opinion moderation of the effectiveness of the internal control system are -0.041 with T-statistic values $1,191<1,660$ at the significance level $\alpha=0.05(5 \%)$ and $\mathrm{P}$ values 0.425 above 0.05 which states that the effectiveness of the internal control system does not moderate the influence of the application of government accounting standards on the achievement of auditor opinion. The results of this study do not support the third hypothesis, namely the effectiveness of the internal control system does not moderate the effect of the application of government accounting standards on the achievement of auditor opinion.

\section{DISCUSSION}

\subsection{Effect of Application of Government Accounting Standards on the Achievement of Auditor Opinions.}

Based on the results of hypothesis testing, the results show that the application of Government Accounting Standards does not affect the achievement of auditor opinion. This is because the Government Accounting Standards are references that have been determined by the Government that must be followed by the Regional Government and the Central Government so that they are mandatory. Rational means that if the Government Accounting Standards that have been compiled are not elaborated and are not obeyed by the Regional Government and the Central Government in the preparation of financial statements, the preparation of financial statements is no longer in line with Government Accounting Standards. Government Accounting Standards are references in the preparation of financial statements if the Regional Government and the Central Government do not follow what has been regulated in SAP, the SAP will not give much influence on the quality of financial statements which ultimately does not affect the achievement of auditor opinion. Auditors provide opinions based on financial statements prepared by the Government, if the preparation of financial statements refers to SAP, it is certain that the financial statements can be accounted for, but if the preparation of financial statements does not refer to SAP, then the financial statements are certainly not accountable.

\subsection{Effect of Effectiveness of Internal Control Systems on Achievement of Auditor Opinions}

Based on the results of hypothesis testing, the results show that the effectiveness of the internal control system influences the achievement of auditor opinion. This is because if the internal control system is good then the goals of the organization or entity can be achieved properly. The purpose of a good internal control system is to maintain the wealth and record of the organization, check the accuracy and reliability of accounting data and improve or encourage efficiency and compliance with management policies or entities. Internal control is weak which results in incomplete accounting records and or inadequate documents available and / or the system does not produce valid accounting data [15]. This condition does not allow the examiner to carry out adequate inspection procedures. As a result of these conditions. the examiner will give an opinion other than Unqualified Fairness. The weaknesses of the internal control system and non-compliance with statutory provisions affect audit opinion [16]. The Internal Control System is a plan that includes the organizational structure and all methods and tools that are coordinated used within the company with the aim of maintaining the security of company property. check the accuracy and correctness of accounting data. encourage efficiency. and help encourage compliance with established management policies so that what has been formulated and planned and implemented by the entity is expected to be in accordance with the Internal Control System prepared by the entity. A good Internal Control System can have a positive impact on the implementation and supervision of the entity. The Internal Control System that applies in the entity is a factor that determines the reliability of financial statements produced by the entity. Therefore, in giving opinion on the fairness of the audit report, the auditor places trust in the effectiveness of the Internal Control System in preventing material errors in the accounting process. Reliability of the Internal Control System is a benchmark for the entity.

\subsection{The Effectiveness of Internal Control Systems Moderates the Effect of Application of Government Accounting Standards on the Achievement of Auditor Opinions}

Based on the results of hypothesis testing, the results show that the effectiveness of the internal control system does not moderate the effect of the application of government accounting standards on the achievement of auditor opinion. Government Accounting Standards are a reference in the preparation of mandatory financial statements. If the Regional Government and Central Government do not follow what has been regulated in SAP, the SAP will not give much influence on the quality of financial statements which ultimately does not affect 
the achievement of auditor opinion, even though it is moderated by the effectiveness of the internal control system.

\section{CONCLUSION AND SUGGESTIONS}

\subsection{Conclusion}

The application of Government Accounting Standards does not have a significant effect on auditor opinion achievement. Government Accounting Standards are references that have been determined by the Government that must be followed by the Regional Government and the Central Government so that they are mandatory. The effectiveness of the internal control system has a significant effect on the achievement of the auditor's opinion but does not moderate the significant influence of the Implementation of Government Accounting Standards on auditor opinion achievement.

\subsection{Suggestion}

Accounting policy is a reference in the preparation of financial statements so that there is a need for sharper accounting policies so that the preparation of financial statements is fully disclosed so that all accounts in the financial statements can be presented carefully in accordance with the mandated Government Accounting Standards.

Regional Governments must further increase their commitment to continuously improve their internal control system by involving all relevant parties, not only inspectors who carry out their own supervision but also each Regional Work Unit must have SOPs for all existing activities so as not to overlap between fields which exists.

\section{ACKNOWLEDGMENT}

This research is a Research Grant from the Directorate General of Higher Education which is included in the Master Thesis Research scheme. Therefore, we would like to express our deepest gratitude to the Directorate of Research and Community Service at the Directorate General of Higher Education for funding this research. Thank you also to the Universitas Mercu Buana Research Center for facilitating the conduct of this research. Likewise, those who have assisted in carrying out this research cannot be mentioned individually

\section{REFERENCES}

[1] T. Kumolo, Politik hukum pilkada serentak, Expose, 2015.

[2] P. Nugraheni, I. Subaweh, Pengaruh Penerapan Standar Akuntansi Pemerintahan Terhadap Kualitas Laporan Keuangan, Jurnal Ilmiah Ekonomi Bisnis, vol. 13(1), 2011
[3] N. Nugraeni, M. Budiantara, Pengaruh Standar Akuntansi Pemerintah Terhadap Kualitas Laporan Keuangan dan Implikasinya Terhadap Akuntabilitas Kinerja, Jurnal Dinamika Ekonomi \& Bisnis, vol. 12(1), 2015.

[4] W. Kieso, Wardield, Intermediate Accounting. United States America: John Willey dan Sons, 2011.

[5] B.S. Purnomo, Pengaruh Sistem Pengendalian Internal Dan Kekuatan Koersif Terhadap Kualitas Laporan Keuangan Pemerintah Daerah, Jurnal Riset Akuntansi Dan Keuangan, vol. 2(1), 2014, pp.276288.

[6] A. Halim, S. Kusufi, Akuntansi Sektor Publik: Teori, Konsep Dan Aplikasi. Jakarta: Penerbit Salemba Empat, 2012

[7] I. Bastian, Sistem Akuntansi Sektor Publik. Jakarta: Penerbit Salemba Empat, 2011.

[8] Governmental Accounting Standards Boards (GASB). Concepts Statement No. 1: Objectives of Financial Reporting in Governmental Accounting Standards Boards Series Statement No. 34: Basic Financial Statement and Management Discussion and Analysis for State and Local Government. Norwalk, 1999.

[9] C.S Warren, P.E.F Reeve, Accounting-Indonesia Adaptation, $25^{\text {th }}$ Ed. Jakarta: Salemba Empat, 2014.

[10] A. Arens, R.J Elder, M.S Beasley, Auditing and Assurance Service anIntegrated Approach, 16th Edition. England: Pearson Education, 2016.

[11] Undang-Undang Republik Indonesia No. 15 Tahun 2004 tentang Pemeriksaan Pengelolaan dan Tanggung Jawab Keuangan Negara

[12] Peraturan Badan Pemeriksa Keuangan Republik Indonesia Nomor 1 tahun 2017 tentang Standar Pemeriksaan Keuangan Negara

[13] M. Arfan, I.A.M Darwanis, The Effect of Understanding of Government Accounting Standard and Internal Control System on Quality Of Finacial Statement From Local Government Through Review Process Of Financial Statement By Inspectorate Agency, Research journal of finance and accounting. vol. 7(4), 2016.

[14] J.S Maabuat, J. Morasa, D.P Saerang, Pengaruh Kelemahan Sistem Pengendalian Internal, Ketidakpatuhan Pada Peraturan Perundangundangan dan Penyelesaian Kerugian Negara Terhadap Opini BPK-RI atas Laporan Keuangan Pemerintah Daerah di Indonesia, Accountability, vol. 5(2), 2016, pp. 52-62.

[15] U. Sekaran, Metodologi Penelitian Untuk Bisnis: Willey, 2017.

[16] O.P Widodo, Sudarno, Pengaruh Temuan Kelemahan Sistem Pengendalian Intern Dan Temuan Ketidak patuhan Terhadap Ketentuan Peraturan Perundang- Undangan terhadap Opini BPK Atas Laporan Keuangan Pemerintah Daerah, 
Journal of Accounting, vol. 6(1), 2017, pp. 25278215 .

[17] H. Setiyawati, Effect of Weakness of the Internal Control System and Non-Comliance With Statutory Provisions on The Audit opinion of The Audit Board of The Republic of Indonesia, Int Journal of Engineering Reasearch and Application, vol. 6(9), 2016, pp. 2248-9622.

[18] A.H Tanjung, Akuntansi Pemerintah Daerah Berbasis Akrual, Cetakan Kedua. Bandung: Alfabeta, 2013.

[19] J.D Campbell, Jardine, McGlynn. Asset Management Excellence. USA: CRC Press Taylor \& Francis Group, 2011.

[20] Committee of Sponsoring Organizations of the Treadway Commission (COSO). Internal Control, Integrated Framework, Executive Summary, Durham: North Carolina. May, 2013.

[21] D. Suwanda, H. Santoso, Kebijakan Akuntansi Berbasis Akrual berpedoman pada SAP. Bandung: Remaja Rosdakarya, 2015.

[22] D.S Pujiono, H. Sukarno, N. Puspitasari, Pengaruh Sistem Pengendalian Intern terhadap Pengelolaan Keuangan Daerah serta Kinerja Pemerintah Daerah, Jurnal Bisnis dan Manajemen, vol. 10(1), 2016, pp. $68-812$.

[23] E. Sisdianto, Nengsih, Analisis Pengaruh Kinerja Keuangan, Realisasi Belanja Modal, dan Pengelolaan Manajemen aset daerah terhadap kualitas laporan keuangan (survey pada pemerintah daerah kota Bengkulu, Provita, vol. 10(1), April, 2017.

[24] U. Gelinas, B.R Dull, Accounting Information Systems, 9th ed. South Western Cengage Learning. 5191 Natorp Boulevard Mason: USA, 2012.

[25] J.A Hall, Accounting Information System, 9th ed. USA: South-Western Cengage Learning, 2014.

[26] N. Hastings, A.J Nicholas, Physical Asset Management: Springer, 2010.

[27] H. Setiyawati, The effect of Internal Accountants' Competence Organizations and the Implementation of the Internal Control System on the Quality of Financial Reporting.Management Invention, vol. 2, 2013, pp.19-27.

[28] Hery, Pengendalian Akuntansi dan Manajemen. Jakarta: Kencana, 2013.

[29] I. Ghozali, Aplikasi Analisis Multivariate dengan Program IBM SPSS23. Edisi 8. Semarang: Badan Penerbit Universitas Diponogoro, 2016.

[30] J. Campbell, McGlynn, Asset Management Excelence, Optimizing Equipment Life Cycle Decisions, Second Edition. Canada: CRC Press Taylor \& Prancis Corp, 2011.

[31] D. Manasae, Public Sector Property Asset Management, John Wiley \& Sons, 2015.
[32] M. Raharja, Pengelolaan Keuangan Dan Aset Daerah (Studi pada Badan Pengelolaan Keuangan dan Aset Daerah, Kabupaten Lamongan), Jurnal Administrasi Publik, vol. 3(1), 2015, pp. 111-117.

[33] M.J Akuba, J.J Sondakh, J.J Tinangon, Dampak Kebijakan Akuntansi Pemerintah Daerah Atas Penerapan Peraturan Pemerintah Nomor 71 Tahun 2010 Dalam Rangka Pemberian Opini Atas Laporan Keuangan (Studi Kasus Pada Dinas Pendapatan Pengelolaan Keuangan Dan Aset Daerah Kabupaten Bolaang Mongondow), Jurnal Riset Akuntansi Dan Auditing Goodwill, vol. 17(2), 2016.

[34] Morisson, Metode Penelitian Survei. Edisi Pertama: Jakarta : Kencana, 2012.

[35] M. Demetouw, A. Salle, M. Asnawi, Pengaruh manajemen aset terhadap optimalisasi aset tetap pemerintah Kabupaten Jayapura, Keuda: Jurnal Kajian Ekonomi Dan Keuangan Daerah, vol. 2(3), 2017.

[36] Mulyadi, Sistem Akuntansi, Edisi Ketiga. Cetakan Keempat. Jakarta : Salemba Empat, 2013.

[37] N. Anggraini, S. Praptoyo, Faktor Yang Menyebabkan Opini Auditor Atas Laporan Keuangan Wajar Dengan Pengecualian, Jurnal Ilmu dan Riset Akuntansi (JIRA), vol. 6(2), 2017.

[38] N.N Afiah, P.C Azwari, The Effect of The Implementation Of Government Internal Control System (GICS) On The Quality of Financial Reporting of The Local Government and Its Impact On The Principle Of Good Governance: A Research In District, City And Provincial Government In South Sumatra, Procedia - Social and Behavioral Sciences, (211), 2015, pp.811 - 818 .

[39] R.H Safitri, B. Aulia, Analisis Faktor yang Mempengaruhi Penentuan Opini pada Laporan Keuangan Pemerintah Daerah (LKPD) Provinsi Sumatra Selatan Berdasarkan Penerapan Standar Akuntansi Pemerintah (SAP), Jurnal Teori dan Riset Administrasi Publik (J-TRAP), 1(1), 2018, pp. 120128.

[40] M.B Romney, P.J Steinbart, Twelfth Edition Accounting Information Systems. United States of America: Pearson Education Limited, 2012.

[41] S. Chodijah, N. Hidayah, Pengaruh Pemanfaatan Teknologi Informasi Dan Sistem Pengendalian Internal Terhadap Kualitas Pelaporan Keuangan Pemerintah Daerah (Studi Kasus SKPD Provins DKI Jakarta), Jurnal Tekun, vol. 8(1), Maret 2018.

[42] A. Sugiama, Gima, Manajemen Aset Pariwisata, Bandung: Guardaya Intimarta, 2013

[43] A. Sukrisno, Auditing, Jakarta: Salemba Empat, 2012.

[44] Sugiyono, Metode Penelitian Kombinasi (Mixed Methods), Bandung : Alfabeta, 2014.

[45] S. Siregar, Statistik Parametrik untuk Penelitian Kuantitatif, Edisi 1, Jakarta : Bumi Aksara, 2015. 
[46] Peraturan Pemeritah Republik Indonesia Nomor 71 tahun 2010 tentang Standar Akuntansi Pemerintahan.

[47] Peraturan Menteri Dalam Negeri RepublikIndoneisa Nomor 64 Tahun 2013 tentang Penerapan Sistem Akuntansi Akrual Pada Pemerintah Daerah.
[48] Peraturan Pemerintah Republik Indonesia nomor 60 tahun 2008 tentang Sistem Pengendalian Internal Pemerintah. 